Renata E. Paliga

\title{
QUARANTINE AS A TOOL OF EPIDEMICS FIGHT
}

\author{
KWARANTANNA JAKO NARZĘDZIE DO WALKI Z EPIDEMIAMI
}

\author{
Pomeranian Medical University in Szczecin \\ Faculty of Medical History and Medical Ethics \\ Pomorski Uniwersytet Medyczny w Szczecinie \\ Zakład Historii Medycyny i Etyki Lekarskiej
}

\begin{abstract}
Until the 19th century, the factor causing epidemics was not known, and the escape from a place where it occurred as well as isolation of patients was considered to be the only effective way to avoid illness and death. Quarantine in a sense similar to modern times was used in 1377 in Ragusa, today's Dubrovnik, during the plague epidemic. It was the first administratively imposed procedure in the world's history. It was later used in Venice and other rich port cities in the Mediterranean. On the territory of today's Poland, quarantine measures were used by the so-called Mayor of the Air - LukaszDrewno in 1623 during the plague epidemic in Warsaw. The quarantine left its mark on all areas of human activity. It affected all humanity in a way that is underestimated today. Throughout history, it has been described and presented visually. It is omnipresent in the world literature, art and philosophy. However, the isolation and closure of cities, limiting trade, had an impact on the economic balance, and the dilemma between the choice of inhabitants' health and the quality of existence, i.e. their wealth, has been the subject of discussions since the Middle Ages.

Since the end of the 19th century, quarantine has lost its practical meaning. The discovery of bacteria and a huge development of medical and social sciences allowed limiting its range. In the 20th century isolation and quarantine no longer had a global range, because the ability to identify factors causing the epidemic, knowledge about the incubation period, carrier, infectiousness, enabled the rational determination of its duration and territorial range.

The modern SARS COV 2 pandemic has resulted in a global quarantine on a scale unprecedented for at least three hundred years. The aim of this paper is to present the history of quarantine from its beginning to the present day, including its usefulness as an epidemiological tool.
\end{abstract}

Keywords: disease epidemic, quarantine, history

\section{STRESZCZENIE}

Do XIX w. nie był znany czynnik wywołujący epidemie, a ucieczkę z miejsca, gdzie wystąpiła oraz izolowanie chorych uważane było za jedyny skuteczny sposób uniknięcia choroby i śmierci. Kwarantanna w znaczeniu zbliżonym do współczesnego została zastosowana w 1377 r. w Raguzie, dzisiejszy Dubrownik, podczas epidemii dżumy. Było to pierwsze w dziejach świata postępowanie nałożone administracyjnie. Później stosowano ją w Wenecji oraz innych bogatych miastach portowych basenu Morza Śródziemnego. Na terenach dzisiejszej Polski, działania o charakterze kwarantanny zastosował tzw. Burmistrz Powietrzny - Łukasz Drewno w $1623 \mathrm{r}$. podczas epidemii dżumy w Warszawie.

Kwarantanna odcisnęła piętno na wszelkich obszarach działalności człowieka. Dotyczyła całej ludzkości w sposób dziś niedoceniony. Na przestrzeni dziejów była opisywana i przedstawiana wizualnie. Jest wszechobecna w światowej literaturze, sztuce, filozofii. Izolacja i zamykanie miast, ograniczanie handlu wpływało jednak na bilans ekonomiczny, a dylemat między wyborem zdrowia mieszkańców a jakością bytu, czyli ich zamożnością - powodował dyskusje już od średniowiecza.

(c) National Institute of Public Health - National Institute of Hygiene / Narodowy Instytut Zdrowia Publicznego - Państwowy Zakład Higieny 
Od końca XIX w. kwarantanna straciła na praktycznym znaczeniu. Odkrycie bakterii oraz olbrzymi rozwój nauk medycznych i społecznych umożliwił ograniczanie jej zasięgu. W XX w. izolacja i kwarantanna nie miały już zasięgu globalnego, ponieważ możliwość identyfikacji czynnika wywołującego epidemię, wiedza o okresie wylęgania, nosicielstwie, zaraźliwości, pozwalała na racjonalne ustalanie czasu jej trwania i wyznaczania zasięgu terytorialnego.

Współczesna pandemia wirusem SARS COV 2 spowodowała ogólnoświatową kwarantannę na skalę niespotykaną od co najmniej trzystu lat. Celem artykułu jest przedstawienie historii kwarantanny od jej początku do współczesności, z uwzględnieniem przydatności jako narzędzia epidemiologicznego.

Slowa kluczowe: epidemie, kwarantanna, historia

\section{INTRODUCTION}

Quarantine can be considered on various levels. A person may discern the events and social factors that changed the quarantine into the epidemiologic tool, as a result of its social phenomenon and the role it played in the development of civilizations. Quarantine can be also perceived as a limitation of freedom for a single unit and whole societies, and eventually it constitutes a factor of controversies leading to the amendments to laws, as well as the establishment of new social priorities and ethical norms.

The origin ofQuarantais 'forty' word. The phenomenon of 'forty' exists in many religions in its symbolic dimension, as well as in pagan and magical rituals (forty days of fasting, forty days of mourning, Jesus stayed at the desert for forty days, Salomon's and David's reign endured forty years, and Hypocrites believed that a disease persisting forty days should be considered a chronic disease, etc.), whereas precise stipulation of origins for such state of affairs is currently problematic (1).

The 'quarantine' is currently defined as the period of compulsory isolation for healthy people, animals and plants arriving from the epidemic regions, that are infected or suspected of infection, with purpose of inhibiting its spread, and the period of quarantine depends on the period of incubation for a particular disease. Another meaning is fencing the space, including the buildings used for isolation (2).

The quarantine word is of particular importance in the twenty first century, as a result of SARS $-\operatorname{coV} 2$ epidemic.

This word was considered archaic last year, and it returned to general discourse in a nick of time. The civilization operating with unbelievable technologies, when compared to former times, that thrives for outer space conquests and boasts of the most widespread access to the healthcare system and education, introduced the isolation in the most compulsory and primitive way. Our modern world was closed down within single days! People at every continent stayed

\section{WSTEP}

Kwarantannę można rozpatrywać na wielu płaszczyznach. Jako zjawisko społeczne lub w kontekście roli, jaką odegrała w rozwoju cywilizacji, można wymienić wydarzenia i czynniki naukowe, które powodowały, że stała się narzędziem epidemiologicznym. Może być postrzegana także jako ograniczenie wolności jednostki lub całych społeczeństw, wreszcie kwarantanna jako czynnik wywołujący kontrowersje prowadzące do zmiany prawa lub ustanawiania nowych priorytetów społecznych i norm moralnych.

Słowo pochodzi od quaranta- czterdzieści. Czterdzieści w wymiarze symbolicznym występuje w wielkich religiach, ale również $\mathrm{w}$ rytuałach pogańskich, magicznych (czterdzieści dni postu, czterdzieści dni żałoby, Jezus przebywał czterdzieści dni na pustyni, Salomon i Dawid rządzili czterdzieści lat, Hipokrates uważał, że po czterdziestu dniach chorobę, która nie ustępuje należy uznać za przewlekłą itp.), a źródło tego stanu rzeczy jest dziś trudne do precyzyjnego ustalenia (1).

Słowo kwarantanna definiuje się współcześnie jako okres przymusowej izolacji zdrowych ludzi, zwierząt, roślin przybyłych z rejonów objętych epidemią, zarażonych lub podejrzanych o zarażenie, która ma na celu zahamowanie jej rozprzestrzeniania, a czas kwarantanny zależy od okresu wylęgania choroby. Kolejnym znaczeniem, jest ogrodzenie przestrzeni wraz z budynkami służące do izolacji (2).

Szczególnego znaczenia nabiera słowo kwarantan$n a$ w XXI wieku, w obliczu pandemii wirusa SARS $-\mathrm{CoV} 2$.

Słowo, które jeszcze w ubiegłym roku uważane było za archaiczne - zostało w krótkim czasie zrehabilitowane. Cywilizacja dysponująca niewyobrażalnymi -w odniesieniu do przeszłości - technologiami, mająca ambicje penetracji kosmosu, która szczyci się największą w dziejach ludzkości masową dostępnością do opieki zdrowotnej i edukacji, zastosowała izolację w sposób obligatoryjny i prymitywny. Świat współczesny został z dnia na dzień zamknięty! Ludzie na wszystkich kontynentach pozostają w domach a słowo 
at homes, and the quarantine word was the most often repeated term in mass media.

At times, when epidemics with global reach were the subject of explicitly historical researches, isolation and escape become the only efficient protection against the unknown pathogen. In these circumstances, the history of quarantine and historic events from Polish medical sciences are worth of noting.

\section{PURPOSE OF THESE PAPERS}

The purpose of these papers is presenting the history of isolation for people, as the important factor in development of civilization, as well as the history of quarantine as a tool of epidemic fight.

\section{MATERIALS AND METHODS}

Historical data, as well as articles and scientific studies in the field of history of medicine, medicine and philosophy, were used in these papers. Literary works were analyzed, as well as the literature touching the subject of this papers, in a critical manner. Attempts were made for interdisciplinary combination of knowledge from the fields of literature, arts, history, history of science and medicine.

\section{ISOLATION AND ESCAPE, AS THE PROTECTIVE MEASURE FOR DISEASE}

People escaped from the infected areas to evade disease and death. Hypocrites encouraged for escape, as a prevention of disease. Everyone tried to escape, even physicians, such as the renown Galen who escaped from Rome during the epidemy (166 AD).

The first documented isolation measuresare treatment methods for Leprosy. Leper hospitals were widely used in ancient times, and the experience obtained from its organization constituted the basis for future administrative solutions at various epidemies.

The records of isolation or detachment, that are applicable to people for medical reasons, can be found in the Bible. In the Book of Leviticus that was finally revised in the sixth or fifth century $\mathrm{BC}$ (the purpose of which was determination of the respective laws for the state of Israel), detailed guidelines for the period of observation, as well as isolation principles for sick people suffering from various skin diseases, with consideration to Leprosy, were included (3).

Herodotus (about 484-426 BC) wrote in „The Histories": "Should any inhabitant of the city suffer from Leprosy (lepra) or have white eruptions (leuke), such a person cannot enter the city or stay with other Persians" (4). Leprosy also was mentioned in the Hippocrates works (about 460-370 BC) and Galen's kwarantanna jest jednym najczęściej powtarzanych w środkach masowego przekazu.

W czasach, gdy o epidemiach o globalnym zasięgu pisali już tylko historycy- izolacja i ucieczka stała się jedyną skuteczną metodą ochrony przed nieznanym patogenem. W tych okolicznościach warto przybliżyć historię kwarantanny oraz przypomnieć fakty historyczne z dziejów polskiej medycyny.

\section{CEL PRACY}

Celem pracy jest przedstawienie historii odosobnienia ludzi jako ważnego elementu w rozwoju cywilizacji, oraz historii kwarantanny jako narzędzia $\mathrm{w}$ walce $\mathrm{z}$ epidemiami.

\section{MATERIAŁ I METODY}

W pracy wykorzystano materiały historyczne, artykuły i opracowania naukowe z zakresu historii medycyny, medycyny i filozofii. Poddano analizie dzieła literackie oraz zastosowano krytyczną ocenę piśmiennictwa dotyczącego podjętego tematu. Dokonano próby interdyscyplinarnego łączenia wiedzy - literatury, sztuki, historii, historii nauki, medycyny.

\section{ODOSOBNIENIE I UCIECZKA JAKO ŚRODEK CHRONIĄCY PRZED CHOROBĄ}

By uniknąć choroby i śmierci uciekano z zakażonych miejsc. Hipokrates zalecał ucieczkę jako profilaktykę choroby. Uciekali wszyscy, również lekarze, np. sławny Galen opuścił Rzym w czasie epidemii w 166 r.n.e.

Najwcześniej udokumentowanym postępowaniem separującym, było traktowanie trądu. Leprozoria stosowano już w starożytności, a doświadczenia zdobywane podczas ich organizacji, stały się podstawą do tworzenia przyszłych rozwiązań administracyjnych $\mathrm{w}$ czasie różnych epidemii.

Zapisy o zastosowaniu odosobnienia czy też oddalenia ludzi z powodów zdrowotnych znajdują się w m. in. w Biblii. W Księdze Kapłańskiej, której ostateczna redakcja nastąpiła w VI lub V w. p.n.e., a celem było ustalenie konkretnych praw w funkcjonowaniu państwa Izrael, zamieszczono dokładne wytyczne dotyczące czasu obserwacji i izolacji chorych na choroby skóry w odniesieniu do trądu (3).

Herodot (ok. 484 -426 r.p.n.e) pisał w „Dziejach”: „jeśli jakiś mieszkaniec miasta ma trad (lepra) lub białe wyrzuty (leuke), nie śmie on przychodzić do miasta ani przestawać z innymi Persami" (4). Wzmianki o trądzie występują także w dziełach Hipokratesa (ok. 460 - 370 p.n.e.) i Galena (ok.130-200 n.e.), jednak 
works (about 130-200 AD), but diseases with epidemic reach occurred in the Medieval times (5).

The Leprosy was the most severe plague of the Medieval times. It degraded the human being in every aspect of social life, as the infected person was condemned to isolation and slow death. The number of infections increased during the Crusades, what obviously correlated with the movement of people, congestion, hard hygienic conditions etc. The Leprosy came to Poland alongside with German settlers and people returning from the Crusades in the thirteen century. The first Leprosy hospitals were established in Glogow, Uniejow, Poznan and Cracow (5). Until the end of the thirteenth century, nineteen thousand places for lepers were established (6).

In the Medieval times, lepers were under custody of church. In 1179, during the Third Lateran Council, principles of isolation were determined. There was a liturgical rite for a person who walked to the Leprosy hospital. With regard to the former importance of the church and glorification of religious life, its purpose was underlining the unique importance of leper's life in the state of isolation. The sick person was blessed with the following words: ,Isolation in this home, to which you enter, will be only physical, but your spirit will always be with us and you will take part in our prayers. Merciful people will take care for your small needs and God will never abandon you. Be careful and be patient. God bless you! Amen."(5).

After the prayer strict prohibitions were spoken loud.They should be mentioned in our current epidemic situation, due to their relevance to limitations and prohibitions imposed on the societies:

"1. I forever prohibit you entering the church, monastery, mill, coming to the market, fair, stay with healthy people.

2. I prohibit you leaving the Leprosy hospital in an outfit other than the leper's outfit.

3. I prohibit you washing the hands or any your belongings in a river, well, and I prohibit you drinking from such places. Should you want water to drink, take it from your barrel and drink it with your bowl.

4. I prohibit you touching anything you want to buy, unless it is your own.

5. I prohibit you coming to tavern; should you want a wine, or you buy a wine, or it is given to you, present your barrel, to which it should be poured.

6. I prohibit you staying with a lady other than your own lady.

7. Should you find another person on your route who wants to talk with you, you cannot talk with such a person in a direction other than downwind. zachorowania o skali epidemii wystąpiły w wiekach średnich (5).

Trąd uważany jest za najbardziej dotkliwą plagę średniowiecza. Przez skazanie chorego na izolację i powolną śmierć, degradował jednostkę w każdym aspekcie życia społecznego. Nasilenie zachorowań obserwowano w czasie wypraw krzyżowych, co było w oczywisty sposób związane z przemieszczaniem ludzi, ich zagęszczeniem, trudnymi warunkami higienicznymi itp. Do Polski trąd został przewleczony przez osadników niemieckich i powracających z wypraw krzyżowych w XIII wieku. Pierwsze leprozoria powstawały w Głogowie, Uniejowie, Poznaniu, Krakowie (5). Do końca XIII w zorganizowano 19 tys. miejsc dla trędowatych (6).

W średniowieczu opiekę nad trędowatymi sprawował kościół. W 1179 r. w czasie III Soboru laterańskiego określono zasady ich izolacji. Powstał obrzęd liturgiczny, który odprawiano nad człowiekiem odprowadzanym do leprozorium. Biorąc pod uwagę ówczesne znaczenie kościoła i gloryfikację życia zakonnego, miał on podkreślić wyjątkowe znaczenie życia trędowatego w odosobnieniu. Chory był żegnany słowami: „Odosobnienie w tym domu do którego wchodzisz będzie tylko cielesne, duchem bowiem zawsze będziesz $z$ nami i będziesz brat udziat w naszych modlitwach. O twoich drobnych potrzebach pomyśla osoby mitosierne a Bóg ciebie nie opuści,. Uważaj tylko i miej cierpliwość. Niech Bóg będzie z Toba. Amen.”(5).

Po modlitwie następowały twarde zakazy, które w obecnej sytuacji epidemicznej warto przytoczyć, ze względu na analogie ograniczeń nałożonych na społeczeństwa świata:

„1. Zakazuję ci na zawsze wchodzić do kościoła, klasztoru, młyna, przychodzić na targ, jarmark, przebywać wśród ludzi zdrowych.

2. Zakazuje ci wychodzić z leprozorium inaczej niż w ubraniu trędowatego.

3. Zakazuję ci myć ręce lub cokolwiek z twoich rzeczy w rzece, studni, zakazuję ci również stąd pić. Jeśli chcesz wody do picia czerp ja ze swojej baryłki i pij swoja czarka.

4. Zakazuje ci dotykać jakiegokolwiek przedmiotu który kupujesz lub targujesz, póty, póki nie będzie twoim.

5. Zakazuję ci wchodzić do karczmy; jeśli chcesz wina- bądź je kupujesz bądź ci je daja podaj swoja baryłkę żeby ci do niej nalano,

6. Zakazuję ci obcować z inna niewiasta niż twoja niewiasta.

7. Zakazuje ci, jeśli spotkasz na drodze inna osobę, która do ciebie zacznie mówić zwracać się inaczej niż pod wiatr. 
8. I prohibit you entering narrow streets, in which a passer-by can be found, who may nearly touch you.

9. Wherever you go, I prohibit you touching the wells and ropes without gloves.

10. I prohibit you touching children and giving them anything.

11. I prohibit you drinking and eating in other way than from your own dishes.

12. I prohibit you drinking and eating in the company of other lepers."(5).

Then, the leper's head was sprinkled with soil from graveyard, and the priest ended the rite with following words "Die for the word, resurrect with God"

\section{BLACK DEATH - THE FIRST QUARANTINE}

The origin of Black Death that very quickly depopulated Europe and led to the end of Medieval times, was the area of Baikal lake (1340), Middle East (7). It was initially brough to Europe by land, with caravans from the Caspian basin, and it arrived to Astrakhan (1346), and Kaffa (1347). The city was under reign of Genoese and in the state of war. The city walls were besieged by Tatars. The army of invaders was weakening, following the Black Death outspread among their flanks. Before the retreat, "the Christian air was spoiled" by plague-stricken bodies thrown over the walls. Since ancient times,making a disease a biological weapon has been a common method of fight (8).

Genoese ships with sails settled from Kaffa outspreaded the Black Death to whole Europe (7).

"Decameron" of Giovanni Boccacciocomes from the period of this epidemy(1349-1351). The author observed the epidemic of pestilence and fled from the city, whereas all his thoughts from the period of isolation laid foundations to this masterpiece of worldwide literature. In prologue, he described in details the symptoms of disease, as well as lacking treatment and behavior of people: "the common malady filled the minds of men and women with such a trepidation, that brother left brother, uncle left nephew and wife left own husband. It was even worse, mothers and fathers left own children without any care, just as they were alien to them"(9). It is assumed that the pestilence pandemic endured until 1356, and 26 million people died (10).

In the Medieval times (1343) the first Committee of Public Health was established, and similar committees were established in Florence, Lucca, Perugia and Pistoia, Ragusa in Dalmatia, in Avignon and Mediolanum, just several years later (1348). Committees were issuing ordinances, in order to isolate the plague vectors (11).
8. Zakazuję ci wchodzić w waska uliczkę gdzie mógtbyś spotkać na drodze przechodnia, który by musiat prawie otrzeć się o ciebie.

9. Zakazuję ci gdziekolwiek idziesz dotykać studzien lub sznurów inaczej niż w rękawiczkach

10. Zabraniam ci dotykać dzieci i dawać im cokolwiek,

11. Zakazuje ci pić i jeść inaczej jak tylko z twoich wlanych naczyń,

12. Zakazuje ci pić i jesść $w$ towarzystwie innych trędowatych."(5).

Po czym następowało posypanie głowy trędowatego ziemią z cmentarza i słowami ,, Umrzyj dla świata z martwych wstań w Bogu" ksiądz kończył obrzęd.

\section{DŻUMA - PIERWSZE KWARANTANNY}

Epidemia dżumy, która spowodowała w krótkim czasie depopulację Europy i przyczyniła się do zakończenia średniowiecza, pojawiła ok. 1340 r. w Azji Środkowej, w okolicach jeziora Bajkał (7). Została przywleczona początkowo drogą lądową, przez karawany od basenu Morza Kaspijskiego, w 1346 r. była już w Astrachaniu i w 1347 r. w Kaffie. Miastem rządzili wówczas Genueńczycy, trwała wojna, a mury oblegali Tatarzy. Armia najeźdźców słabła przez szerzącą się w jej szeregach epidemię dżumy. Przed odwrotem, na pożegnanie , zepsuto chrześcijanom powietrze" wrzucając przez mury ciała zadżumionych. Walczono sposobem stosowanym od czasów starożytnych po dzisiejsze wykorzystując chorobę jako broń biologiczną (8).

Wypływające z Kaffy statki genueńczyków rozwlekły dżumę na całą Europę (7).

Z czasu wspomnianej powyżej epidemii pochodzi „Dekameron” napisany przez Giovanniego Boccaccia w latach 1349-1351. Autor był świadkiem zarazy, a jego ucieczka z miasta i przemyślenia podczas izolacji przyczyniły się do powstania dzieła, które na setki lat stało się kanonem literatury światowej. W prologu, bardzo dokładnie opisał objawy choroby, brak skutecznego leczenia oraz zachowania ludzi: „powszechna klęska taka trwoge w umysłach mężczyzn i kobiet sprawita, że brat opuszczat brata, wuj siostrzeńca, siostra brata, a nawet żona męża swego. Gorzej jeszcze, że ojcowie i matki zostawiali dzieci swoje nie troskajac się o nie zupetnie, jakby im catkiem obcymi byty"(9). Przyjmuje się, że pandemia dżumy trwała do 1356 r. a w jej czasie umarło 26 milionów ludzi (10).

Już w późnym średniowieczu, w 1343 r., powstała w Wenecji pierwsza komisja zdrowia publicznego. W 1348 komisje takie powoływano we Florencji, Lucce, Peruggi i Pistoi, Raguzie w Dalmacji, Awinionie i Mediolanie. Komisje wydawały zarządzenia mające na celu min. izolowanie nosicieli zarazy (11). 
It was very quickly observed, that people fleeing from onsets of plague support the epidemic spread. On the other hand, closed trade routes and cities raised objections of trade communities and burgess. All items brought from epidemic regions were initially destroyed, even whole ships were burned. Such activities raised objections of merchants, and cities were pauperized. The dilemma of public health vs. finances and economy was present even in the Medieval times. People started to wonder, whether there is a tool inhibiting the expansion of plague, simultaneously enabling proper functioning of the city. Such organizational solutions and first legal records were formulated in rich countries, with development based on the commercial exchange.

It is assumed that the first case of quarantine, as an official measure, occurred in Ragusa (currently Dubrovnik), in 1377. The President of the Republic of Ragusa ordained the compulsory isolation for all people arriving to the city at an island located nearby the shore, for the period of thirty days (de Mercano island), before entering the port. The date of this ordinance is strictly known, it was July 27, 1377 (10).

Few months later, similar measures were undertaken in Venezia, where the mandatory fortyday quarantine was ordained before entering the port. Medical certificates were issued for seamen after the quarantine, thus the first public healthcare office was established in Europe, also informing the physicians about current epidemiologic situation in the city (6).

In the rich Venezia, first hospitals of all times, for pestilence treatment, were established. The purpose of such places was isolation of people, and provision of proper healthcare, both (12). In the agest the „Lazaret” term, that is synonymous to hospital (or army hospital) in Polish language, was the general name for a place designated to treat the sick people during the epidemy in the Western countries (13). This term originates from the name of the Venetian island, Saint Maria from Nazareth (Santa Maria di Nazaret), at which the first hospital was established (1423). It was maintained from the funds of rich citizens - merchants or town folk of Venezia (10). Until the end of the nineteenth century, locating the people on an island during the epidemy was a popular practice, both for quarantine and treatment purposes.

Epidemics were quite common at territory of Poland. Długosz wrote about "the pestilential atmosphere" in the year 1003, 1006 and 1007. Plagues in the cities required new laws and sanitary regulations. City councilors resolved so called Danzig law, in order to stop the plagueand guarantee comfort to citizens. The city of Cracow (1364) ordained prohibition of cattle slaughter within the city walls, pouring impurities through the window onto by-passers, and cleaning
Bardzo szybko zaobserwowano, że ludzie uciekający z miejsc zadżumionych przyczyniają się do rozszerzania epidemii. $Z$ kolei zamknięcie miast czy szlaków handlowych budziło sprzeciw środowisk kupieckich i mieszczaństwa. Początkowo niszczono przedmioty przywiezione $\mathrm{z}$ terenów epidemii, nawet palono całe statki. Działania te budziły sprzeciw kupców i ubożenie miast. Dylemat - zdrowie społeczne czy finanse i ekonomia był obecny już w średniowieczu. Zaczęto więc myśleć o stworzeniu narzędzia zapobiegającego rozszerzaniu zarazy, a jednocześnie pozwalającego na funkcjonowanie miast. Takie rozwiązania organizacyjne i pierwsze zapisy prawne stworzono w bogatych państwach świata, których rozwój opierał się na wymianie towarów.

Uznaje się, że pierwszy raz zastosowano kwarantannę jako postępowanie urzędowe w 1377 r. w Raguzie (obecnie Dubrownik). Prezydent Republiki Raguzy zarządził dla wszystkich przybywających do miasta konieczność spędzenia trzydziestu dni na jednej z wysp znajdujących się u wybrzeża (wyspa de Mercano), zanim zostaną wpuszczeni do portu. Znana jest dokładna data rozporządzenia - 27 lipca 1377 r. (10).

Kilka miesięcy później podobne kroki podjęto w Wenecji, zarządzając konieczność czterdziestodniowej kwarantanny przed wejściem do portu. Tam wydawano zaświadczenia o stanie zdrowia dla marynarzy po odbyciu kwarantanny, tworząc tym samym pierwszy urząd zdrowia w Europie, którego zadaniem było również informowanie lekarzy o aktualnym stanie epidemiologicznym w mieście (6).

W bogatej Wenecji, powstały pierwsze w dziejach szpitale przeznaczone do leczenia chorych na dżumę. Nie były jedynie miejscem izolacji, lecz niesienia pomocy (12). Słowo „Lazaret” będące w języku polskim synonimem szpitala, czy szpitala wojskowego, było przez wieki w krajach zachodu ogólnie przyjętą nazwą miejsca przeznaczonego do leczenia chorych zakaźnych podczas epidemii (13). Pochodzi od nazwy weneckiej wyspy Św. Maria z Nazaretu (Santa Maria di Nazaret), na której w 1423 r. powstał pierwszy szpital epidemiczny. Utrzymywany był z funduszy bogatych mieszkańców - kupców i mieszczan Wenecji (10). Należy podkreślić, że umieszczanie ludzi na wyspach - w celu kwarantanny czy leczenia chorych, w czasie epidemii było popularną praktyką do końca XIX w.

$\mathrm{Na}$ terenach Polski epidemie występowały często. Długosz w kronikach opisał „powietrze morowe” już w 1003, 1006 i 1007 r. Masowe choroby pojawiające się w miastach wymogły ustanawianie praw i przepisów sanitarnych. Rajcy miejscy uchwalali tzw. wilkierze mające na celu jej powstrzymanie i zapewnienie mieszkańcom komfortu życia. W Krakowie, w 1364 r., wyszedł zakaz zabijania bydła w mieście, wylewania nieczystości przez okno na przechodniów, w 1373 r. - 
the streets nearby own houses,(1373) (14). In 1543, prohibition covered meetings in taverns, using city bath-houses, temporary inhabitants had to leave the city, and the deceasedhad to be buried outside the city. The streets had to be cleaned from impurities and mud, butchers could not slaughter the animals within the city walls, any used belongings could not be resold, as well as particular city gates were closed (14).

In 1588, gravediggers with families had to wear uniforms with special markings (black cloths with special marks). Hayduks watched sick people with their families from entering the streets, as well as doors of infected houses were boarded up. In the subsequent years and during next epidemics, Sigismund III Vasa issued his personal ordinances "one cannot let anybody into the city Cracow, apart from people who come to the market with foodstuffs" or in 1602: "nobody cannot accommodate a guest or let him into own house, under penalty of death" (14).

Everybody fled from the plague, when it was possible. The city council, rich town folk and merchants made for cottage residences or went to relatives.

The first regulatory document for sanitary activities was the ordinance for compulsory residence of pharmacists in the city, issued by Sigismund III Vase (1613), whereas the first scientific discourse concerning the proceedings at the epidemic times was the work of Sebastian Petrycy "Instructionsand guidelines for behavior during plague" (1613) (15).

In Warsaw, during one pestilence epidemy in the seventeenth century, a place of isolation and quarantine was established at the Vistula, precisely at Kępa Polkowska, next to current Żoliborz district, and this place was not preserved until our times. Records can be found that during the plaguein September, 1605, sick people were located there (16). It should be noted, that people with infection were maintained from city funds. During the next epidemy of Black Death at Warsaw (1624), at this island wooden buildings with separate kitchens were erected, and sick people did not communicate with each other (16). During the above noted plague, Łukasz Drewno, having the profession of pharmacist, was appointed for the position of so called "Air Mayor" and organized the efficient sanitary services. For example, he ordained the construction of isolation wards outside the city walls, as well as organized the porter, gravedigger and city guard services. It is said that epidemiologic researches were conducted by him, as he evidenced every death and every new infection. On the basis of daily reports, he ordained the evacuation of endangered locations (15). It was the first written record of similar organizational activities in Poland.

It was commonly believed that the God punishes the people with plague for their guilts, and in the face nakaz porządkowania ulicy przy domach (14). W 1543 roku zabroniono spotykania się w karczmach, korzystania z miejskich łaźni, niemieszkający na stałe mieli opuścić miasta, pochówki osób zmarłych podczas epidemii miały być organizowane poza murami. Nakazano uprzątnięcie z ulic nieczystości i błota, zakazano rzeźnikom zabijania zwierząt w mieście, zamknięcie niektórych bram miejskich oraz sprzedawania jakichkolwiek używanych rzeczy (14).

W 1588 roku nakazano grabarzowi i jego rodzinie nosić specjalnie oznaczone ubiory (czarne płaszcze ze specjalnymi znakami). Hajducy pilnowali, by chorzy $\mathrm{i}$ ich rodziny nie pojawiali się na ulicy, zabijano deskami drzwi zakażonych domów. W kolejnych latach i kolejnych epidemiach pojawiały się osobiste zarządzenia króla Zygmunta II Wazy „abyście nikogo do Krakowa nie puszczali oprócz tych ludzi, którzy z żywnościa na targi przyjeżdzaja” lub w 1602 roku: , aby żaden pod gardlem nie śmiat gościa wszelakiej kondycji przyjmować ani w dom wpuszczać" (14).

Kto mógł uciekał przed zarazą. Władze miasta, bogate mieszczaństwo, kupcy, udawali się do wiejskich posiadłości, lub krewnych.

Pierwszym dokumentem regulującym działania sanitarne był wydany przez Zygmunta II Wazę w 1613 roku nakaz pozostania aptekarzom w mieście, a pierwszą rozprawą naukową o znaczeniu dla postępowania w czasie epidemii była wydana przez Sebastiana Petrycy „Instrukcja albo nauka jak się sprawować w czasie moru" 1613 r. (15).

W Warszawie, w czasie jednej z epidemii dżumy w XVII w., powstało miejsce odosobnienia i kwarantanny na Wiśle, na Kępie Polkowskiej (przyp.aut znajdowała na wysokości obecnej dzielnicy Żoliborz), która nie przetrwała do czasów współczesnych. Zachowały się zapisy, że we wrześniu 1605 r., w czasie zarazy, umieszczano tam chorych (16). Godny podkreślenia jest fakt, że zakażeni byli utrzymywani dzięki finansom miasta. Podczas kolejnej epidemii dżumy która nawiedziła Warszawę w 1624 r., wybudowano na wyspie budynki drewniane z odrębnymi kuchniami, aby chorzy nie komunikowali się ze sobą (16). W czasie wspomnianej zarazy tzw. „Burmistrzem Powietrznym" był Łukasz Drewno, aptekarz, który zorganizował sprawnie działającą służbę sanitarną. Zarządził min. zbudowanie poza miastem izolatki dla chorych, zorganizował służby tragarzy, grabarzy, strażników miejskich. Można powiedzieć, że prowadził „,badania epidemiologiczne", ponieważ zapisywał każdy zgon i nowy przypadek zachorowania. Na podstawie codziennych raportów zarządzał ewakuację zagrożonych terenów (15). Był to pierwszy opisany przypadek podobnych działań organizacyjnych w Polsce.

Powszechne było wówczas przekonanie, że Bóg zsyła zarazę na ludzi jako karę za grzechy, a w obli- 
of helpless physicians or any logical explanation for the origin of epidemy, people crowded at worships pleading for salvage. Since the end of the seventeenth century, there have been rumors of notable plague outspread, because of such worships in Europe (also at territory of Poland). Hierarchs also pointed out this phenomenon. Despite warnings and prohibitions, believers crowded in churches in order to search for hope in the collective prayers (17).

\section{THE ONSET OF SOCIAL MEDICINE AND THE FIRST EPIDEMIOLOGIC OFFICES}

In the eighteenth century, the origin of diseases was still unknown. Experiences from former generations were implemented in the epidemic fight. Since the seventeenth century, well-organized Healthcare Offices were operating in the respective cities of France, particularly in the cities with ports. Harbor cities had to implement and organize the quarantine for ships arriving from epidemic areas.

Tremendous development of cities and general overcrowding were in opposition to hygienic standards. The Enlightenment philosophical trends were rejecting the immaterial and divine influence on the reality, whereas social disorders led to the populistic policies of the government, in order to improve the living conditions in the society. As a result, a new discipline, currently called the public health, was formulated, and France was the unquestionable leader in its development in the nineteenth century(18). In the seventies of the eighteenth century, numerous epidemics outspreaded in Europe (i.e. smallpox, malaria, pestilence, venereal diseases). In Paris, the epidemic situation was very serious and became the additional hotspot for social disorders.

The French Revolution on the canvas of the equality and justice slogans introduced new institutions under the control of the Government. In 1870, the Healthcare Committee was established, in order to take care for social health and the poorest people.

Administration of Napoleon Bonaparte introduced two offices - the health officer (officier de sante) and the epidemic physician (medecins des epidemies). Following the Napoleon's decree of 1805, a new fulltime "epidemic physician" was appointed in every district(18). During the infectious disease epidemy, there were quick and measurable effects resulting from the noticeable "national care for every citizen", with means of the respective funds on hygiene, compulsory smallpox vaccination, cleaning the streets and epidemic surveillance. In addition, the origins of diseases were perceived in other way. Bereaving the infection of the unknown element with goodish origin is currently known as "medicalization of a disease". czu bezradności medyków i braku jakiegokolwiek logicznego wyjaśnienia przyczyn epidemii wierni tłumnie uczestniczyli w nabożeństwach błagalnych o zachowanie od moru. Już od końca XVII w. w Europie (i na terenach Polski) głoszono poglądy o wybitnym przenoszeniu choroby w czasie tych uroczystości. Hierarchowie Kościoła również zwracali uwagę na tę okoliczność. Jednak mimo ostrzeżeń i zakazów, ludzie gromadzili się szukając nadziei w zbiorowej modlitwie (17).

\section{NARODZINY MEDYCYNY SPOŁECZNEJ I PIERWSZYCH URZĘDÓW EPIDEMICZNYCH}

W XVIII w. nadal nie zanano przyczyny powstawania chorób. W walce $\mathrm{z}$ epidemiami korzystano z doświadczeń poprzednich pokoleń. Już od XVII w. niektóre miasta Francji - szczególnie portowe, miały sprawnie funkcjonujące tzw. Urzędy Zdrowia. Miasta nadmorskie były zobowiązane do stosowania i organizowania kwarantanny dla statków przybywających $\mathrm{z}$ terenów epidemicznych.

Olbrzymi rozwój miast i panujące w nim przeludnienie nie sprzyjały higienie. Oświeceniowe trendy filozoficzne odrzucające niematerialny -boski wpływ na rzeczywistość, niepokoje społeczne, wymusiły na rządzących formułowanie programów populistycznych mających na celu polepszenie warunków życia ludności. W ten sposób kształtowała się nowa dziedzina, nazywana dziś zdrowiem publicznym, a niekwestionowany prymat w jej rozwoju do połowy XIX w., należał do Francji(18). W latach siedemdziesiątych XVIII w., nawiedziły Europę liczne epidemie chorób zakaźnych (ospa, malaria, dżuma, choroby weneryczne i inne). W Paryżu sytuacja epidemiczna była poważna i stawała się dodatkowym elementem zapalnym prowadzącym do niepokojów społecznych.

Rewolucja Francuska, w konsekwencji haseł równości i sprawiedliwości, wprowadziła nowe instytucje kontrolowane przez Rząd. W 1870r., m.in powołano Komitet Zdrowotności do walki o zdrowie ludu i najuboższych.

Administracja Napoleona utworzyła dwa stanowiska - lekarza urzędowego (officier de sante) oraz lekarza epidemicznego (medecins des epidemies). Dekretem Napoleona w 1805 r. w każdym okręgu został powołany etatowy „lekarz epidemiczny” (18). Przeznaczenie środków na higienę, obowiązkowe szczepienia na ospę, sprzątanie ulic, nadzór epidemiczny w razie wystąpienia epidemii choroby zakaźnej -dawały szybkie i wymierne efekty w postaci widocznego „dbania państwa o obywatela”. Zmienił się też status postrzegania przyczyn chorób. Odarcie z pierwiastka nieznanego, zesłanego przez Boga, nazywany jest dziś „medykalizacją choroby”. Spowodował lawinę hipo- 
It resulted in the avalanche of hypotheses and theses. Dogmas were overturned in many disciplines of science, consequently accelerating the development of medical sciences(19).

The world has been changing in many respects, in the mental, social and political way. Wars, military conquests and colonialism generated the movement of people, following various reasons. In turn, such a movement accelerated the outspread of infectious diseases with a wider reach. The developing healthcare and social politics completed the concept of 'new humanization of modern societies'.

\section{QUARANTINE AS AN ATTRACTION DURING JOURNEYS}

In the eighteenth and nineteenth century, people travelled very extensively, in order to extend own knowledge, see new continents, or simply satisfy own curiosity. The literature produced background for this fashion, with its inherent element of exotics and orientalism. Even today, these trends can be observed in the arts of dress, interior design, paintings and music from that period (the premiere of Mozart's opera, "The Abduction from the Seraglio", for example, was warmly welcomed in spite of its imperfection, because it included Turkish elements). The epidemic outbreaks of infectious diseases were present in many places of the world, thus the unexpected and compulsory quarantine had to be taken into account by prospective travelers. Organization of isolation usually depended on local government, thus travelers treated the quarantine as another attraction during the journey, because they neither have influence on it, nor on its course...

Conditions of quarantine in the eighteenth century were quite the same as in the Medieval times. Jean Jacques Rousseau, who influenced much the French (and worldwide) culture, philosophy and politics in the eighteenth century with own works and beliefs andgave literary backgrounds to new era of Romanticism, described the quarantine in the renown and scandalizing "Confessions". The Ship he travelled undergone the three-week quarantine in Genoa (1743). The people on board could select the place of isolation. They could stay on the ship, or spend it in a remote and completely empty building. Rousseau was the only one who selected isolation on land. He slept on the floor in own clothes and covered up with own cloak. He strolled whole days within the confines of empty, two-story building. He was watched from outside. Meals were delivered by soldiers with bayonets, who summoned him with a bell (21). He ate meals in a sitting position on the stairs and have seen resemblance to Robinson Cruzoe. It should be noted, that Daniel Daffoe, when tez i twierdzeń prowadzących do obalenia dogmatów w różnych dziedzinach nauki i w konsekwencji rozwoju medycyny(19).

Świat zmieniał się pod wieloma względami- mentalnym, społecznym, politycznym. Wojny, podboje militarne, polityka kolonialna, generowały przemieszczanie się ludzi w różnych celach. To z kolei prowadziło do szybszego i dalszego roznoszenia chorób zakaźnych. Kształtująca się polityka zdrowotna i społeczna była dopełnieniem koncepcji nowej humanizacji nowoczesnych społeczeństw.

\section{KWARANTANNA JAKO ATRAKCJA PODRÓŻY}

W XVIII i XIX w. ludzie podróżowali bardzo chętnie,- $\mathrm{W}$ celu pogłębienia wiedzy, poznania nowych kontynentów, lub po prostu ciekawości. Modę podsycała literatura, której nieodłącznym elementem była egzotyka i orientalizm. Trendy widoczne są po dziś dzień w sztuce ubioru, wystroju wnętrz, malarstwie i muzyce tamtego czasu (np. premiera opery Mozarta „Uprowadzenie z seraju” w 1781 r. wzbudziła entuzjazm mimo niedopracowania, ponieważ przedstawiła elementy tureckie). Ogniska epidemiczne chorób zakaźnych pojawiały się w różnych miejscach świata, więc podróżujący musieli liczyć się z tym, że zostaną zatrzymani w niespodziewanej, przymusowej kwarantannie. Organizacja izolacji zależała zazwyczaj od lokalnych władz, więc podróżni nie mając wpływu na jej egzekwowanie ani przebieg, traktowali nieplanowaną kwarantannę jako atrakcję podróży...

Warunki osiemnastowiecznej kwarantanny były często podobne do średniowiecznej. Jean Jacques Rousseau, którego dzieła i poglądy wywarły olbrzymi wpływ na kulturę, filozofię i politykę osiemnastowiecznej Francji (i świata), który przygotował literaturę na nową epokę - romantyzm (20), opisał kwarantannę w sławnych i skandalizujących „Wyznaniach”. Statek, którym podróżował w 1743 r. poddano w Genui trzytygodniowej kwarantannie. Ludzie płynący na jego pokładzie mogli wybrać miejsce izolacji - pozostać na statku lub spędzić czas w oddalonym i zupełnie pustym budynku. Rousseau, jako jedyny, wybrał miejsce na lądzie. Spał na posadzce, na swoich ubraniach, przykrywał podróżnym płaszczem, siedział na walizce, spacerował całe dnie po pustym dwukondygnacyjnym budynku. Był pilnowany z zewnątrz, a posiłki przynosili mu uzbrojeni w bagnety żołnierze, którzy przywoływali go dzwonkiem (21). Spożywał siedząc na schodach i porównywał siebie do Robinsona Cruzoe. Nie można w tym miejscu nie wspomnieć o tym, że Daniel Daffoe pisząc swoje dzieła („Dziennik roku zarazy”, „Przypadki Robinsona Kruzoe”), również 
writing the "A Journal of the Plague Year" and "Robinson Crusoe" masterpieces, was also inspired by quarantine and pestilence epidemy, that was observed by him during childhood in London (1661).

During the quarantine, Rousseau wrote letters and complied with the hygienic recommendations for objects from that times: "I send the letter after washing it in vinegar, incensed and smoked"(21). He spent two weeks in this way, then he continued his journey.

Quarantine was also experienced by Juliusz Slowacki, who travelled to Palestine from Italy, through Greece. He spent it on a desert, nearby the ElArish harbor city, Egypt (1836). He wrote the following words: "...They threatened us with a sword, made free Bedouins to camp on the sand in the tents and live this way for more than a week, under the surveillance of guards and a doctor; there is no other route from Egypt to Syria. When travelling on a camel, I had to share their fate"(22). This Poet heard the story of the former camp inhabitant, in similar circumstances, who endured the death of seven children and own wife. The story was told by a doctor taking care for the people in quarantine. On canvas of this story, Slovacki wrote a moving poem. The words are touching until today, whereas practical aspects, even technical details of the organized quarantine, are interesting to us, and all of this in Africa between the eighteenth and nineteenth century.

Slowacki wrote in the name of "Black Death father", who mourned after the death of son:

"I took the corps and thrown to guards.

They took the corps on iron scrappers,

They took him to the Black Death yards.

From that night on grief filled my heart

And I was ordained another forty days of

quarantine" (22)

The same parent, after the death of another daughter:

"The guards came and wrestled her body

So carelessly, with hook she was caught

Caught on the breast, so stiff, round and white,

And aye, as they had no God in their hearts!

They tore her apart in my own eyes!"

The wretched father questioned the God with agelong questions, searched for a covenant and bargained:

"After the death of three, I did not believe!

"The God calls for all little ones of me!" inspirował się kwarantanną i epidemią dżumy, którą przeżył w dzieciństwie w Londynie w $1667 \mathrm{r}$.

W czasie kwarantanny Rousseau pisał listy stosując się do ówczesnych zaleceń higieny przedmiotów:, wystatem list obmyty w occie, okadzony $i$ wspótspalo$n y$ '(21). Spędził tak dwa tygodnie zanim ruszył w dalszą podróż.

Kwarantanny doświadczył również Juliusza Słowacki podczas podróży z Włoch przez Grecję, Palestynę. Odbył ją na pustyni, niedaleko miasta portowego El-Arish w Egipcie w 1836 r. Pisał: ,„.. pod kara miecza zmusit wolne beduiny rozbijać na piasku namioty $i$ żyć dni kilkanaście pod dozorem straży i doktora; inaczej zaś z Egiptu do Syrii dostać się nie moga. Podróżując na wielbłądzie, podobnemu musiałem ulec losowi"(22). Lekarz opiekujący się osobami w kwarantannie opowiedział poecie historię człowieka, który w tym miejscu, w podobnych okolicznościach, przeżył śmierć siedmiorga dzieci i żony. Na kanwie tej opowieści Słowacki napisał poruszający poemat. Wersy liryczne wzruszają po dziś dzień, jednak interesujące są dziś praktyczne aspekty, wręcz techniczne szczegóły organizacji kwarantanny w północnej Afryce końca XVIII i początku XIX w.

Słowacki pisał w imieniu „Ojca zadżumionych”, który po śmierci syna rozpaczał:

$$
\begin{aligned}
& \text { „Porwatem trupa i rzuciłem straży } \\
& \text { Aby go wzięła na żelazne zgrzebła } \\
& \text { I tam gdzie grzebia zadżumionych, grzebła } \\
& \text { Od tamtej nocy tak petnej boleści } \\
& \text { Wyznaczono mi nowych dni czterdzieści” (22) }
\end{aligned}
$$

Ten sam rodzic, po śmierci kolejnej córki:
„Strażnicy przyszli mi wydrzeć to ciało
I nieostrożnie zaczepili hakiem-
Hak padt na pierś jej twarda, kragła, biata
I tu- bogdajby jak ja nie umarli!
Tu ja pod moimi oczyma rozdarli"

Nieszczęsny ojciec zadawał Bogu odwieczne pytanie, szukał z nim przymierza i targował się:

„Nie wierzytem, żeby wziawszy troje

Bóg mi chciat zabrać wszystkie dzieci moje"

Mimo rozwoju nauki, w XXI w., pytanie pozostaje bez odpowiedzi- dlaczego nie każdy choruje i umiera? Ojciec rodziny, mąż pożegnał żonę, która najprawdopodobniej zaraziła się przez pocałunek najmłodszego dziecka :

„Ja, co me wszystkie calowatem trupy

$Z$ tej kwarantanny wychodzilem zdrowy" (22) 
Despite the development in science in the twentyfirst century, one question is being still unanswered. Why not everybody sickens and die? The father and husband bid last good bye to own wife, who was most probably infected by the kiss of the youngest child:

"I, who kissed all corpses of mine

End this grief quarantine completely sound..."(22)

\section{CHOLERA MORBUS \\ AND THE CHANGES TO THE WORLD}

In France, in the beginning of the nineteenth century, opponents to the theory of infection were increasing in numbers. Bacteria were unknown and the origins of diseases were diversely perceived (miasmas, contagium animatum, viviparity, etc.). Opponents to the theory of infectious diseases were sitting in the Healthcare Council of Paris, the Royal Medical Academy. They were also active among the ranks of hygienists, attacked the sanitary regulations, particularly the police and quarantines!(18). False logic was their guidance. According to them, isolation of people made no sense, because a disease cannot be transferred from one human being to another.

In the nineteenth century, the Asian cholera was the predominant infectious disease of Europe. Approximately 40 million people died during this pandemic. It should be noted that during the military activities of the November Uprising (1830) cholera crossed the boarders of Asia and Europe. It is curious, why people decided to begin the uprising during so severe epidemic threat? The evidences for widespread epidemic in Russia in early autumn and the implemented quarantine can be found both in the official records and the memories or letters of renown people (i.e. Alexander Pushkin). This poet wrote to his intended Natalia: „entry to Moscow is forbidden, thus I am closed down in Boldin [...] did you abandon Moscow?[...] it is obvious our marriage cannot take place this cursed year [...] in the matter of us, we are closed for quarantine and plague did not reach us" (23).

First infections occurred after the Battle of Ignan (April 10, 1831), and the Central Healthcare Committee for Epidemic Fight was established eight days later. According to the initial statements, the disease was not infectious, thus sanitary cordons and quarantine were obsolete. The above stated beliefs were enforced by physicians from the government of France, in order to obtain the knowledge of unknown disease. Indisputably, the epidemic significantly strengthened the fall of the November Uprising (it could be even the decisive factor) (24). Cholera disease reached the whole world, despite sanitary cordons at country boarders,

\section{CHOLERA MORBUS I ZMIANA ŚWIATA}

We Francji na początku XIX w., coraz donośniej słychać było głosy przeciwników teorii zakaźności. Nie znano bakterii, a hipotezy na temat przyczyn chorób były rożne (miazmaty, contagium animatum, żyworództwo itp.). Przeciwnicy teorii zakaźnej chorób zasiadali w Radzie Zdrowia Paryża, Królewskiej Akademii Medycyny, byli aktywni wśród higienistów, atakowali ustawodawstwo sanitarne- szczególnie policję i kwarantanny!(18). Kierowali się logiką - skoro choroba nie przenosi się z człowieka na człowieka, to nie ma sensu ludzi izolować.

W XIX w. dominującą chorobą zakaźną w Europie, była cholera azjatycka. Podczas pandemii umarło ok. $40 \mathrm{mln}$ ludzi. Na podkreślenie zasługuje fakt, że cholera przekroczyła granice Azji i Europy podczas działań wojennych powstania listopadowego w $1830 \mathrm{r}$. Można dziś zastanawiać się, dlaczego podjęto decyzję o rozpoczęciu powstania w czasie poważnego zagrożenia epidemicznego. Bo o tym, że epidemia szalała wczesną jesienią w Rosji, że stosowano tam wówczas kwarantannę, świadczą nie tylko urzędowe zapisy, lecz wspomnienia i listy sławnych osób, min. Aleksandra Puszkina. Poeta pisał do narzeczonej Natalii: „wjazd do Moskwy zostat zakazany i oto jestem zamknięty w Bołdinie [...] czy Pani wyjechata z Moskwy?[...] jasne że w tym roku (niechaj będzie on przeklęty) nasz ślub się nie odbędzie [...] jeśli zaś o nas chodzi, to jesteśmy zamknięci kwarantannami, a zaraza jeszcze do nas nie przeniknęta"(23).

Pierwsze zachorowania pojawiły się po bitwie pod Iganiami 10 kwietnia 1831r., a osiem dni później powołano Komitet Centralny Zdrowia do walki z epidemią. Na początku twierdzono, że choroba nie jest zakaźna, a kordony sanitarne, czy kwarantanna są zbędne. Poglądy powyższe były forsowane przez lekarzy przysłanych przez rząd Francji w celu zapoznania się z nieznaną chorobą. Niezaprzeczalnie, epidemia przyczyniła się w znaczący sposób do upadku powstania listopadowego (być może była czynnikiem decydującym o porażce) (24). Cholera rozprzestrzeniała się na cały świat mimo stosowania kordonów sanitarnych na granicach państw, powoływania komitetów ekspertów, czy organizowania kwarantann, również dla armii (25).

W obliczu licznych epidemii w Europie, emigracji do Kanady i Stanów Zjednoczonych Ameryki, coraz szybszych i popularniejszych podróży, w 1834 r. zaproponowano podjęcia opracowania międzynarodowych standardów i przepisów dotyczących min. kwarantanny. W 1851 r. odbyła się w Paryżu Pierwsza Międzynarodowa Konferencja Sanitarna (26). W Stanach Zjednoczonych Ameryki, w 1866 r., Rada Higieny miasta Nowy York wykorzystała model francu- 
the enacted expert committees, or quarantines also covering the army (25).

In the face of numerous epidemics in Europe, the emigration to Canada and USA, as well as faster and more popular journeys, the first draft international norms and regulations, covering i.e. Quarantine, were implemented in 1834. In 1851, the First International Sanitary Conference was organized in Paris (26). In the United States (1866) the Council of Hygiene of New York implemented the French model when organizing the medical services, as well as the New York Board of Health was enacted. A collection of quarantine regulations in New York was firstly enacted in 1878, and the agreement was reached between the United States and Europe, on the matter of international infectious disease information and unification of quarantine regulations, in 1893.

It took nearly one hundred years since the objections of numerous environments to the phenomenon of quarantine to reach the respective agreement. During this dispute, many people perceived this preventive measure as the oppressive tool, depriving the general crowd of foodstuff and resources.

In the nineteenth century the science undergone a general development. Former dogmas, very often rooted in the ancient times, were overturned. Statistical methods were implemented into the medical observation, as well as control groups were introduced in order to evaluate the results of treatment in an objective manner, etc. (27).

Simultaneously to development of aseptics and antiseptics, people raised postulates of replacing the isolation and escape with physical and chemical methods.

For economic and political elites, the idea of replacing the quarantine with disinfectants was very promising and attractive. Thanks to the application of chlorine, carbolic and alcohol derivatives, among others, scientific backgrounds were found for herbal censing in the Medieval times.

Discovery of bacteria (Robert Koch), the fermentation phenomenon (Luis Pasteur), aseptics and antiseptics (Ignaz Semmelweis, Joseph Lister, Erns von Bergmann, Jan Mikulicz -Radecki, Wiliiam Halsted and others), as well as development of optical instruments (microscope), remarkably pushed the knowledge of infectious diseases forward.

In the years 1870-1914, national governments, as well as various commercial, business and colonial lobbies, perceived the microbiology and parasitology as the priority fields of knowledge. It should be noted, that the European countries fought for own share of the world in the nineteenth century. Colonies were the source of supplies for raw materials, trade zones for goods and services, as well as proper solution for ski organizacji służb medycznych powołując Zarząd Zdrowotności Nowego Yorku (18). Dopiero w 1878 r., po raz pierwszy w Nowym Jorku uchwalono zbiór przepisów, które dotyczyły kwarantanny, a w 1893 r., w Stanach Zjednoczonych i Europie osiągnięto porozumienie $\mathrm{w}$ sprawie międzynarodowego informowania o chorobach zakaźnych i wdrożono ujednolicenie przepisów (26).

Do względnego porozumienia doszło po prawie stu latach sprzeciwu licznych środowisk wobec kwarantanny. W czasie trwania sporu nie brakowało tych, którzy postrzegali to rozwiązanie prewencyjne jako narzędzie do ciemiężenia ludzi, które zabiera chleb i źródło utrzymania.

XIX w. był czasem wielkiego rozwoju nauki. Obalano dotychczasowe dogmaty, zakorzenione często w starożytnych poglądach. Do obserwacji medycznej dołączono elementy statystyki, wprowadzono grupy kontrolne w celu obiektywnego zbadania skuteczności leczenia itp. (27).

W miarę rozwoju aseptyki i antyseptyki, zaczęto postulować zastąpienie izolacji i ucieczki przed chorobą na walkę z nią przez środki fizyczne czy chemiczne.

Myśl o zastąpieniu kwarantanny dezynfekcją była obiecująca i wybitnie atrakcyjna dla elit ekonomiczno-politycznych. Średniowieczne okadzanie ziołami otrzymało naukowe uzasadnienie przez stosowanie pochodnych chloru, karbolu, alkoholu i innych.

Odkrycie bakterii (Robert Koch), zjawiska fermentacji (Luis Pasteur), aseptyki i antyseptyki (Ignaz Semmelweis, Joseph Lister, Erns von Bergmann, Jan Mikulicz-Radecki, Wiliiam Halsted i inni), rozwój przyrządów optycznych (mikroskop) spowodowały niebywałe przyspieszenie w poznaniu natury chorób zakaźnych.

W latach 1870-1914 mikrobiologia i parazytologia stały się dziedzinami priorytetowymi dla władz państwowych i różnego rodzaju lobby: handlowych, biznesowych, kolonialnych. Nie można zapominać, że druga połowa XIX w. to walka między krajami europejskimi o podział świata. Kolonie zaopatrywały w surowiec, były rynkami zbytu dla towarów i usług, miały rozwiązać kwestię przeludnienia. Trudno dziś określić, jaki procent działań wspierających rozwój bakteriologii, epidemiologii czy higieny był podyktowany działaniami prowadzącymi do ograniczenia kwarantanny statków i towarów, która przynosiła olbrzymie straty ekonomiczne. Niezaprzeczalnie, w czasie olbrzymiego rozwoju naukowego i społecznego, u schyłku XIX w., traktowano kwarantannę jako narzędzie prymitywne, a obligatoryjne wprowadzanie i brak kontroli nad lokalnymi administratorami, był traktowany jako niesprawiedliwość ponieważ mógł prowadzić do nadużyć. 
overcrowding. Stipulation of the percentage factor for activities supporting development of bacteriology, epidemiology and hygiene, and resulting from the demanded limitation of quarantine for ships and goods (with tremendous economic losses), is currently problematic. During the great social and scientific development, at the verge of the nineteenth century, the quarantine was indisputably perceived as a primitive tool.Moreover, its compulsory implementation and lacking control on local governments was treated as injustice, because of possible misuses.

\section{QUARANTINE AS THE EPIDEMIOLOGIC TOOL}

In the nineteenth century, quarantine was used as the healthcare service tool. After discovery of bacteria and successful experiences with aseptics and antiseptics, it was time for the separation measures with background of scientific methods. The respective activities were implemented, respectively to the property of microbe generating the epidemic. There were national and international institutions that protected the population against any pandemic.

After the World War One, the typhoid fever, dysentery, pestilence, Spanish flu and other epidemics took place in Europe. In Poland (after the independence 0 the general society fought with various infectious diseases, whereas typhoid fever was the most infectious one.

In the western countries, people believed that typhoid fever can make a greater disaster than the sole war, and Lenin spoke the famous words: „either the louse wins socialism or socialism wins the louse" (28). The end of the Polish-Soviet War enabled new international activities. Ludwik Rajchman was the worldwide known expert and the manager of the Hygiene Organization of the League of Nations. The international sanitary agreement between Poland and Russia was most probably undersigned thanks to his involvement. It was realized, that a coordination is required for activities at territories of both countries for the prevention of typhoid fever, due to turmoil of war and migration of people (28). The epidemic flow from Russia to the western parts of the continent was indisputably stopped in Poland, thanks to the decisive activities of Polish services.

After the World War Two, the isolation of Breslau (1963) during the smallpox epidemy (with its origins in Asia) was the most spectacular quarantine measure. Breslau was closed down for several months and the city was encircled with sanitary cordon. Vaccination, quarantine and other isolation activities were implemented on a large scale (29).

\section{KWARANTANNA JAKO NARZĘDZIE EPIDEMIOLOGII}

W XX wieku kwarantanna stosowana była jako narzędzie w służbie nauki. Po odkryciu bakterii, po doświadczeniach związanych ze stosowaniem aseptyki i antyseptyki, kierując się dowodem naukowym zaczęto stosować działania separujące. Podejmowano działania w zależności od właściwości drobnoustroju wywołującego epidemie. Działały instytucje państwowe i międzynarodowe, których celem była ochrona populacji przed pandemiami.

Po pierwszej wojnie światowej w Europie panowały epidemie duru plamistego, czerwonki, dżumy, grypy hiszpanki i innych. W Polsce po uzyskaniu niepodległości, walczono z różnymi chorobami zakaźnymi, z których najbardziej ekspansywny był dur plamisty.

Na zachodzie sądzono, że dur plamisty może stać się większą tragedią niż sama wojna, a Lenin powiedział słynne: "albo wesz zwycięży socjalizm albo socjalizm zwycięży wesz"(28). Po zakończeniu wojny polsko-bolszewickiej stały się możliwe działania międzynarodowe. Ludwik Rajchman był wówczas uznanym światowym ekspertem i kierownikiem Organizacji Higieny Ligii Narodów. Najprawdopodobniej dzięki jego zaangażowaniu podpisano międzynarodową umowę sanitarną między Polską a Rosją. Zdawano sobie sprawę, że ze względu na zawirowanie wojenne i migrację ludności konieczne jest skoordynowane działanie na terenach obu państw w celu powstrzymania epidemii duru plamistego (28). Niezaprzeczalnie, dzięki zdecydowanym działaniom polskich służb, pochód epidemii z Rosji na zachód kontynentu, został w Polsce zatrzymany.

Po drugiej wojnie światowej, najbardziej spektakularną kwarantanną w Polsce była izolacja Wrocławia podczas epidemii ospy prawdziwej przywleczonej z Azji w 1963 r. Zamknięto wówczas na kilka miesięcy Wrocław, miasto otoczono kordonem sanitarnym, wprowadzono szeroko szczepienia, kwarantannę, i inne działania izolujące (29).

\section{WNIOSKI}

Znaczenie i rozumienie kwarantanny ewoluowało na przestrzeni wieków. Jako ucieczka przed zarazą w starożytności stała się w XX w. narzędziem w służbie nauki. Początkowo stosowano kwarantannę w bogatych miastach portowych, a w celu jej organizacji chętnie wykorzystywano wyspy. Na terenach Polski, z oczywistych względów historycznych i uwarunkowania geograficznego przejmowano zalecenia wypracowane w innych krajach.

Kwarantanna kształtowała cywilizację pośrednio i bezpośrednio. Działanie pośrednie na otoczenie czło- 


\section{CONCLUSIONS}

The importance and knowledge of quarantine evolved in centuries. It evolved from the escape from plague in Ancient times, to the medical science tool in the twentieth century. It was initially implemented in rich harbor cities, and islands were readily used during its organization. At territories of Poland, for obvious historic reasons and following its geographical conditions, recommendations from other countries were easily adopted.

The quarantine shaped the civilization in direct and indirect manner. Indirect activities, that acted on the surrounding of a human being, encouraged for new organizational solutions, for example in the public zones. Whereas, its direct influence on a human being induced development of new skills in individuals. The quarantine and isolation favorized the creative units. For centuries, people from many countries lived with a threat of lethal disease. They operated with epidemiologic threat in their minds, got used to it and treated it as the obvious living background.

In the twentieth century, isolation and quarantine had not been implemented globally, due to the possible identification of the infectious factor, the knowledge of incubation, carriers and infectiousness, what enabled rational determination for duration of epidemy and its territorial reach.

In the twentieth century, population of Europe forgot about this global threat, thanks to the preventive measures (i.e. vaccination) in particular countries and activities of international organizations. Quarantine was applied locally and without publicity. It became the underestimated preventive tool guaranteeing the epidemiologic balance.

In the beginning of the twenty-first century, epidemics with global reach seemed to be impossible, and infectious diseases were perceived as an archaic phenomenon unimaginable in the safe and well-fed Europe. A global bio-terroristic threat was not present in common minds, for obvious reasons.

In 2020, the escape solution still holds true in confrontation with an unknown virus, similarly to the Medieval times. During quarantine, the medieval sailing ships were at anchors nearby islands. Today, large cruise ships are drifting on the seas. In the Middle Ages, people fled from the pestilence cities, outspreading the disease. Today, people with the suspected infection flee from the emergency wards, due to the fear of quarantine. Doors of public health workers are marked and the sole workers are called to abandon own residences, there is also a "hunt" on sick persons in the Internet. A comparison can be made to isolation of people with pestilence, whose doors were boarded up and belongings were burned down. wieka, zmuszało do szukania nowych rozwiązań organizacyjnych m.in. w sferach publicznych. Natomiast bezpośredni wpływ na człowieka powodował rozwój nowych umiejętności poszczególnych osób. Kwarantanna i izolacja sprzyjała jednostkom kreatywnym. Ludzie przez wieki żyli ze świadomością zagrożenia śmiertelną chorobą. Funkcjonowali $\mathrm{z}$ zagrożeniem epidemicznym, przyzwyczajali się, traktując to jako oczywiste tło życia.

W XX w. izolacja i kwarantanna nie miały już zasięgu globalnego, ponieważ możliwość identyfikacji czynnika wywołującego chorobę, wiedza o okresie wylęgania, nosicielstwie, zaraźliwości, pozwalała na racjonalne ustalanie czasu trwania epidemii i wyznaczania jej zasięgu terytorialnego.

W XX w., ludność Europy dzięki programom profilaktycznym (m.in. szczepienia ochronne), poszczególnych państw, jak i działaniom organizacji międzynarodowych, zapomniała o globalnym zagrożeniu. Kwarantanna stosowana lokalnie i bez rozgłosu, stała się niedocenianym narzędziem służącym do utrzymania dobrostanu epidemicznego.

Na początku XXI w. epidemie o ogólnoświatowym zasięgu wydawały się niemożliwe, a choroby zakaźne postrzegano jako zjawisko archaiczne, niewyobrażalne w sytej i bezpiecznej Europie. Globalne zagrożenie bioterrorystyczne, z oczywistych względów, nie było obecne w powszechnej świadomości.

W 2020 r., w obliczu walki z nieznanym wirusem pozostaje jak w średniowieczu - ucieczka. Średniowieczne żaglowce stały u wysp na kwarantannie- dziś dryfują wielkie wycieczkowce. W średniowieczu ludzie uciekali z zadżumionych miast roznosząc zarazę, teraz podejrzani o chorobę uciekają z SOR, w obawie przed umieszczeniem w kwarantannie. Tak jak zamykano zadżumionych i dla pewności zabijano deskami drzwi domów i palono dobytek, tak oznacza się drzwi pracowników służby zdrowia, wzywa do opuszczania miejsc zamieszkania i „poluje” w Internecie na zakażonych. Medycy, przez wieki dokonywali wyboru -uciekać czy zostać ryzykując życie, i w obecnym czasie borykają się z podobnym dylematem.

Globalna pandemia i poczucie zagrożenia uwidoczniły różnice $\mathrm{w}$ mentalnym rozwoju poszczególnych społeczeństw. Postrzeganie restrykcyjności środków zaradczych w czasie epidemii jest wypadkową doświadczenia, zmian mentalnych wynikających z potrzeb i obowiązujących priorytetów moralnych. Dobro ludzi czy ekonomia? Zdrowie publiczne jest dobrem czy zamożność społeczeństw? Chociaż nadal notuje się wiele nowych zakażeń i umierają ludzie, nie brakuje głosów negujących zagrożenie. Protestujący przeciw ograniczeniom nakładanym przez służby państwowe (przemieszczania, kwarantanny, zamyka- 
Doctors had to make similar choices in every century. Should I escape, or risk own life? The same dilemma is valid at our times.

The global pandemic and the sense of threat revealed discrepancies in mental development of particular societies. Perception of the restrictive nature of preventive measures during the epidemic is the resultant of experience and mental changes, according to the needs and binding moral priorities. Should we care for people or economy? Should we care for public health or public wealth? Despite many new infections and deaths, there are many people who still negate the threat. Opposers to prohibitions of national services (relocation, quarantine, closed down commercial spaces, bars and restaurants) invoke postulates from past ages...

In the twenty-first century, quarantine and social isolation is still the primitive and simply the only efficient method of fighting with pandemic threat of unknown etiology.

\section{THE END}

Quarantine, particularly as a limitation of freedom, is a driving factor for various manipulations and conspiracy theories. It is ironic that Karol Irzykowski wrote the following drama, "Plague in Bergamo" (1897), and its analysis reveals psychological mechanisms of crowds during the unimaginable death march of epidemic. He created it at times, when psychology evolved into science. This masterpiece made controversies and was not understood by general mass. The author located the libretto plot in Bergamo. Similarly to the ancient times, this Italic city was devastated by a disease, that had an epidemic reach. There are reasons why Danish writer, Jeans Peter Jakobsen, wrote that "Bergamo is famous of plagues" (1882) (30).

People make quarantine journals during the epidemic of our times, similarly to former ages. Currently, journals are in the digital form. Such journals could be a valuable testimony for future generations who may learn from them more about us and our civilizationthan from scientific discourses published in the articles with the highest citation factor.

\section{REFERENCES}

1. Lebas $F$, Une symbolique trop carrée mise en quarantaine, ou comment le sens de quatre peut contrecarrer la symbolique. Revue de Sémantique et Pragmatique [En ligne], 35-36 | 2015, mis en lignele 01 mars 2016, consulté le 09 mai 2020. URL : http://journals.openedition.org/rsp/1586 ; DOI : https://doi.org/10.4000/rsp.1586 nia punktów usługowych, barów, restauracji) przytaczają argumenty sprzed wieków...

W XXI w., kwarantanna i izolacja społeczna pozostaje prymitywnym i w swej prostocie jedynym skutecznym sposobem uniknięcia zakażenia w obliczu pandemii o nieznanej etiologii.

\section{ZAKOŃCZENIE}

Kwarantanna jako ograniczenie wolności jest wdzięcznym narzędziem do różnego rodzaju manipulacji i do snucia teorii spiskowych. Na ironię losu zakrawa fakt, że dramat: „Zaraza w Bergamo” Karola Irzykowskiego z 1897 r., przedstawia mechanizmy psychologii tłumu podczas niewyobrażalnego pochodu śmierci w czasie epidemii. Powstał w czasie, gdy psychologia kształtowała się jako nauka, a o psychologii społecznej jako takiej nikt jeszcze nie myślał. Utwór przyjęty został niechętnie i bez zrozumienia. Autor umieścił akcję libretta w Bergamo. I jak przed wiekami, w czasie współczesnej epidemii, włoskie miasto, Bergamo zostało przez chorobę tragicznie doświadczone.. Nie bez kozery „Bergamo zarazami stynie" pisał duński pisarz Jeans Peter Jakobsen w 1882 r. (30).

W czasie obecnej epidemii, jak przed wiekami ludzie prowadzą dzienniki z czasu zarazy - tym razem w formie cyfrowej. Być może, będą wartościowym przekazem dla następnych pokoleń, które więcej wyczytają z nich prawdy o nas i obecnej cywilizacji, niż z naukowych traktatów publikowanych w artykułach o najwyższych współczynnikach cytowania.

2. Markowski A, Pawelec R, Wielki słownik wyrazów obcych i trudnych, Warszawa: Wyd. Wilga; 2002:428; podobnie Kopaliński W, Słownik wyrazów obcych i zwrotów obcojęzycznych, wydanie XVI, Warszawa: Wyd. Wiedza Powszechna; 1989:289.

3. Pismo Święte Starego i Nowego Testamentu, najnowszy przekład $\mathrm{z}$ języków oryginalnych z komentarzem, Częstochowa: Wyd. Święty Paweł; 2009:203.

4. Grmek D,M, Historia chorób u zarania zachodniej cywilizacji, Warszawa: Wyd. W.A.B. 2002:220223.

5. Szumowski W, Historia medycyny filozoficznie ujęta, Kęty: Wyd. Marek Derewiecki, 2008: 262.

6. Nosko J, Zachowania zdrowotne i zdrowie publiczne aspekty historyczno- kulturowe, Łódź: Instytut Medycyny Pracy, 2005:134,138,141.

7. Ruffié J, Sournia J, CH, Historia epidemii. Od dżumy do AIDS, Warszawa: Wyd. W.A.B.; 1996 :86. 
8. Whellis M, Biological Warfare ad the 1346 Siege of Caffa, Emerg Infect Dis, 2002; (8), 9 :973.

9. Boccaccio G, Dekameron, przekład E. Boyé, Wrocław: Wyd. Siedmiogród, 2017:10.

10. Mafart B, Perret J-L, Histoire du koncept de Qatantaine, Med Trop 1998, 58, 2: 14- 20.

11. Gilewska - Dubis J, Diagnostyka, terapia i profilaktyka chorób zakaźnych w średniowiecznej medycynie europejskiej. W: Płonka-Syroka B, Srogosz T, red. Zdrowie i choroba jako problem polityczny i społeczny. Medycyna w kontekście działań państwa, Wrocław: Wyd. DiG, 2005: 27.

12. Seyda B, Dzieje medycyny w zarysie, Warszawa: PZWL, 1973:168 -169.

13. Bańko M, red. Wielki słownik wyrazów bliskoznacznych, Warszawa: PWN, 2005:785.

14. Zmudziński A, Historia działań sanitarnych i przeciwepidemicznych w Krakowie i Małopolsce. W: Bukowski J, Bilek M, red. Od królewskich edyktów do inspekcji sanitarnej, historia działań sanitarnych i przeciwepidemicznych w Krakowie i Małopolsce, Kraków: Wyd. ArtPress, 2007:2832.

15. Rucińska B, Historia polskich instytucji sanitarno epidemiologicznych ze szczególnym uwzględnieniem uregulowań prawnych ich działalności. W: Bukowski J, Bilek $\mathrm{M}$, red. Od królewskich edyktów do inspekcji sanitarnej, historia działań sanitarnych i przeciwepidemicznych w Krakowie i Małopolsce, Kraków: Wyd. ArtPress, 2007:41.

16. Wejnert A, Opis historyczny trzech kęp na Wiśle, (Polkowska, Bełk, Saska) od najdawniejszych czasów do 1850 roku, Warszawa 1850:4-6.

17. Kracik J, Staropolskie Postawy wobec zarazy, Kraków: Wyd. Petrus, 2012:96.

18. NoskoJ, Ku nowożytnej koncepcji troski o zdrowie publiczne. Intelektualne przywództwo Francji, Arch Hist Fil Med, 1997, 62, 3:261- 290.

19. Płonka- Syroka B, Problem chorób zakaźnych w okresie nowożytnym i współczesnym jako element polityki państwowej. W: Płonka Syroka B, Syroka A, red. Leczyć uzdrawiać pomagać, Wrocław: Wyd: Arboretum, 2007:165.

20. Tatarkiewicz W, Historia filozofii t.2, Warszawa: PWN, 2007:170-174.

21. Rousseau, Wyznania, przełożył Tadeusz Boy Żeleński, Warszawa: Wyd. Hachette, 2009:375376.

22. Słowacki J, Ojciec Zadżumionych, w El- Arish. W: Juliusz Słowacki, dzieła wybrane, Krzyżanowski J, oprac, Wrocław: Wydawnictwo Ossolińskich, 1979:169-283.
23. Orłowski J, Aleksander Puszkin a epidemia cholery w 1930 roku w Rosji. W: Łoch E,Wallner G, Flis Czerniak E, red. Człowiek wobec epidemii chorób zakaźnych od starożytności po czasy współczesne w świetle literatury i medycyny część IX, Lublin: Wyd: UMCS; 2011:77 - 94.

24. Paliga R, Cholera podczas powstania listopadowego 1830-1831. Organizacja służb medycznych i metody leczenia. W: Kmieciak B, Paliga R, Korzeniowska J, Wyzwania innowacyjnej medycyny, aspekty historyczne prawne i kliniczne. Katowice: Wyd. Sophia; 2016:31-60.

25. Notatki Oficera Polskiego o obchodzeniu się Rządu pruskiego z korpusem wojska Polskiego (weszłego z Litwy do Prus pod dowództwem Gienerała Giełguda w czasie trwającej 53 dni kwarantanny) w Paryżu w 1833, WWW.polona.pl dostęp 10.06. 2020

26. Conti A, A, Quarantine Trough History, International Encyclopedia of Public Haelth 2008 :454- 461. http://ncbi.nim.nih.gov data dostępu 19.05.2020.

27. Zieliński A, Jak medycyna stałą się nauką, Przegl Epidemiol 2014;68:161- 168.

28. Balińska M, A, 80-lecie Państwowego Zakładu Higieny, Roczniki Państwowego Zakładu Higieny, suplement, 1998; 49:91.

29. Kostrzewski J, Magdzik W, Epidemie ospy w Polsce w latach 1953- 1963, Przegl Epidemiol 1964;18:141 - 151 .

30. Waligóra J, Młodopolska dis cors Concordia „Zaraza w Bergamo" Karola Irzykowskiego. W: Łoch E,Wallner G, Flis -Czerniak E. red. Człowiek wobec epidemii chorób zakaźnych od starożytności po czasy współczesne w świetle literatury i medycyny część IX, Lublin: Wyd. UMCS; 2011: 113 -122.

Received: 18.06.2020

Accepted for publication: 27.07.2020

Otrzymano: 18.06.2020 r.

Zaakceptowano do publikacji: 27.07.2020 r.

\section{Address for correspondence:} Adres do korespondencji:

Renata E. Paliga

Zakład Historii Medycyny i Etyki Lekarskiej

Pomorski Uniwersytet Medyczny

ul. Rybacka 1

70 -204 Szczecin

rpaliga@pum.edu.pl 